\title{
DROSERA X FONTINALIS (DROSERACEAE), THE FIRST NATURAL SUNDEW HYBRID FROM SOUTH AMERICA
}

\author{
Fernando Rivadavia • 1 Daniel Burnham Court • San Francisco, California, 94109 - USA • \\ fe_riva@uol.com.br
}

Keywords: New taxa: Drosera $\times$ fontinalis, Drosera grantsaui, Drosera tomentosa, South America.

Received: 16 June 2008

Introduction

Artificial Drosera hybrids are known from several subgenera and sections in the genus Drosera, such as $D$. capensis L. $\times D$. slackii Cheek, D. neocaledonica $\mathrm{R}$. Hamet $\times D$. aliciae R. Hamet, $D$. nidiformis Debbert $\times D$. dielsiana Exell \& Laundon, $D$. burmannii Vahl $\times D$. sessilifolia A. St.Hil., D. kenneallyi Lowrie $\times D$. lanata K. Kondo, D. dichrosepala Turcz. $\times$ D. roseana N.G. Marchant \& Lowrie, D. anglica Huds. $\times$ D. spatulata Labill., D. oblanceolata Y. Z. Ruan $\times$ D. capillaris Poir., D. macrantha Endl. $\times$ D. andersoniana W. Fitzg. ex Ewart. \& White, and even complex hybrids such as $D$. (falconeri $\mathrm{K}$. Kondo \& $\mathrm{P}$. Tsang $\times$ ordensis Lowrie $) \times D$. (darwinensis Lowrie $\times$ falconeri) (Kusakabe 1979; Snyder 2000; Ziemer 2002). A smaller number of natural hybrids are known, such as: D. allantostigma (N.G. Marchant \& Lowrie) Lowrie \& Conran $\times$ D. omissa Diels, D. omissa Diels $\times$ D. pulchella Lehm. (Lowrie \& Conran 2007), D. aliciae $\times$ D. glabripes (Harv. ex Planch.) Stein (Gibson \& Green 1999), as well as between most northern temperate taxa (Schnell 2002). Furthermore, a few Drosera species are almost surely of hybrid origin, such as D. anglica Huds. (Wood 1955) and D. tokaiensis (Komiya \& Shibata) T. Nakamura \& Ueda (Hoshi et al. 1994; Nakano et al. 2004).

In 1994 near the town of Grão Mogol in Minas Gerais state, southeastern Brazil, plants intermediate between $D$. grantsaui and $D$. tomentosa were found at a site where both species were sympatric. Further studies showed these intermediate plants were present at numerous other localities where the two species grew sympatrically or in neighboring habitats in Minas Gerais, Goiás, and Bahia states. This is the first hybrid, natural or artificial, reported between native South American Drosera species (Rivadavia 2003 , where $D$. tomentosa was treated as $D$. montana var. tomentosa). Its morphological and ecological characteristics are discussed below, with the help of illustrations and a distribution map.

\section{Results}

Drosera $\times$ fontinalis Rivadavia hybrida nova, D. grantsaui Rivadavia $\times$ D. tomentosa A. St.Hil. Type: Brazil, Minas Gerais, Grão Mogol, 9/Sep./1994, Rivadavia 302 (SPF) (see Figure 1).

Drosera $\times$ fontinalis Rivadavia, hybrida nova, D. tomentosa A. St.-Hil. $\times$ D. grantsaui Rivadavia, sed folia suberecta lanceolata, semina lacrymoidea.

Perennial herbs with semi-erect leaves in rosettes (see Figures 3, 4). Stipules rectangular, membranaceous, translucent white to pinkish or bronze in color, $1.8-4.5 \mathrm{~mm}$ long and $0.5-1.6 \mathrm{~mm}$ wide at the base, the upper 1/2-1/3 divided into numerous filaments. Leaves green to wine-red in color, lanceolate, abaxially more or less sparsely eglandular-pilose to nearly glabrous; petioles 3-7 mm long and 0.5-1.0 mm wide, glabrous adaxially; lamina 4-11 mm long, 1-3 mm wide, adaxially covered with numerous retentive glands. Inflorescences erect, 1-3 per plant, 10-36 cm long (including 
scape), rarely bifurcating at the apex, 2-12 flowers each, increasingly glandular-pilose (in number and size) towards the apex of the inflorescence, more or less eglandular-pilose on the lower half (or not at all), increasingly so (in number and size) towards the base of the scape; bracts ovate-filiform, 0.1-1.0 mm long, densely glandular-pilose and with rare eglandular hairs; pedicels 3-6 mm long, inserted 5-12 mm apart, glandular-pilose; sepals 5, oblong-ovate, 3-4 mm long, abaxially glandularpilose, united at basal 1/4-1/5 of length; petals 5, obovate-cuneate, 4-6 mm long, light pink-lilac in
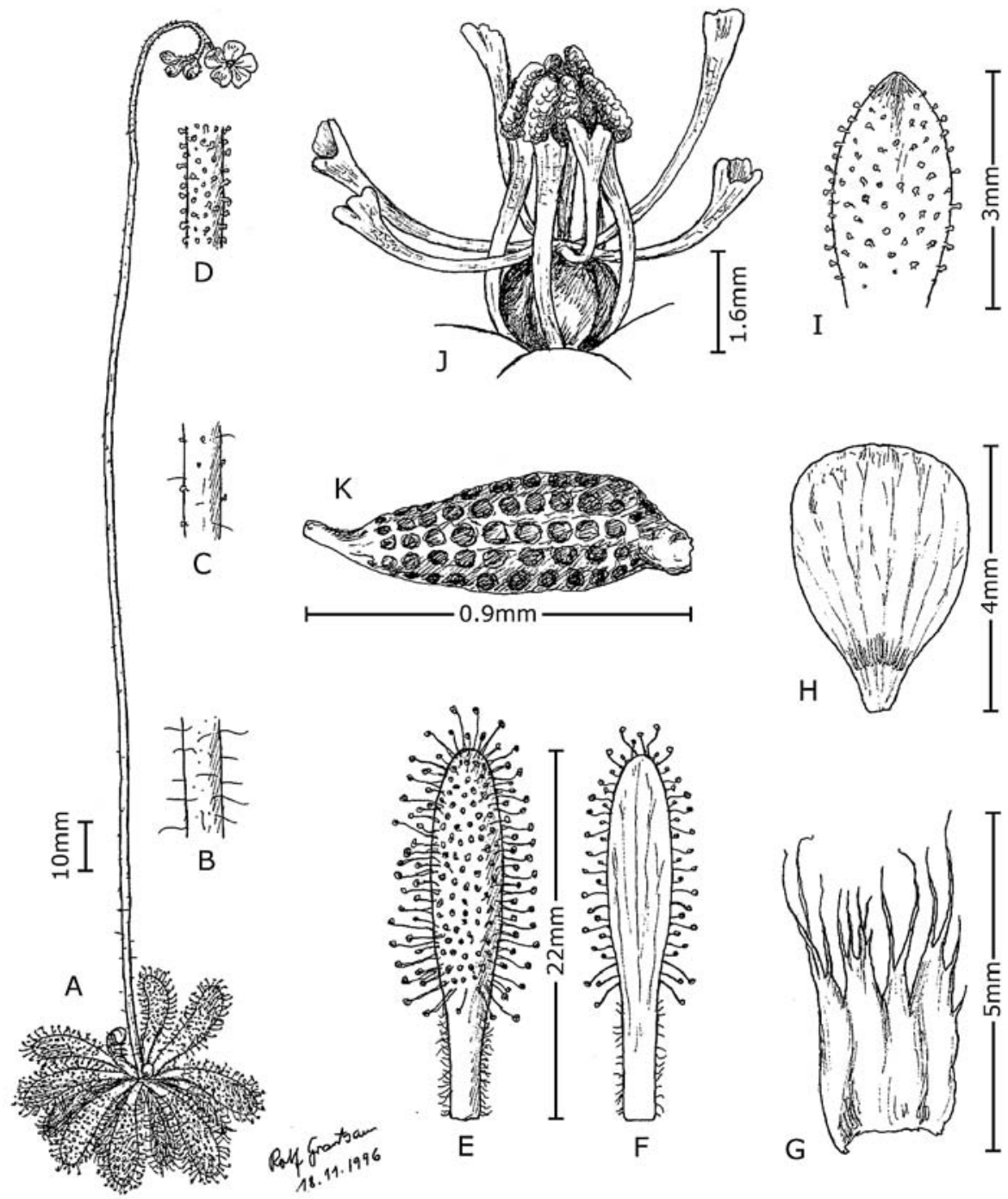

Figure 1: Drosera $\times$ fontinalis Rivadavia; A: habit; B: detail of indumentum near the base of the scape; C: detail of indumentum halfway up the scape; D: detail of indumentum on the upper portion of the scape; E: leaf, adaxial view; F: leaf, abaxial view; G: stipule; H: petal; I: sepal; J: gynoecium and stamens; K: seed. Based on cultivated live specimens from Itacambira, Minas Gerais (herbarium specimens from this location deposited at SPF: Rivadavia 309). 
color; ovary ellipsoid-obovate, trilobed, 1.5-1.8 mm long at anthesis; carpels 3; styles 3, bifurcated at the base, 2-3 mm long, stigmata bilobed to flabellate and often cupped; stamens 5, $3 \mathrm{~mm}$ long, anthers 1.0-1.5 mm long; seeds black, lacrimoid, reticulated, 0.2-0.9 mm long and 0.05-0.1 $\mathrm{mm}$ wide (smaller ones appear to be undeveloped ovules).

Specimens examined: BRAZIL. Bahia: Abaíra, Catolés, Campo da Mutuca, 23/Mar./1992, Stannard \& Silva 52793 (SPF) (mixed collection with D. grantsaui); Abaíra, Catolés, trilha para o Campo da Mutuca, 29/July/1995, Rivadavia \& Ganev 492 (SPF); Piatã, Serra do Santana, 13/Jul./2005, Rivadavia et al. 2004 (SPF). Goiás: Alto Paraíso de Goiás, estrada Brasília-A.Paraíso, 14/Apr./1995, Rivadavia \& Ogassavara 382 (SPF); Alto Paraíso de Goiás, estrada A.ParaísoTeresina de Goiás, 19/Mar./1997, Rivadavia 654 (SPF); Alto Paraíso de Goiás, estrada A.ParaísoTeresina de Goiás, 23/Jun./2007, Rivadavia \& Batista 2626 (SPF). Minas Gerais: Botumirim, Serra da Canastra, 21/Dec./1994, Rivadavia 340 (SPF); Botumirim, Serra da Canastra, 13/Oct./2001, Rivadavia 1272 (SPF); Grão Mogol, 7km ao sul da cidade, 15/Oct./1988, Harley et al. 25067 (SPF); Grão Mogol, Morro do Jambeiro, Rivadavia 286, 3/June/1994 (SPF); Grão Mogol, Rivadavia 292, 7/Sep./1994 (SPF); Grão Mogol, Morro do Jambeiro, 8/Sep./1994, Rivadavia 301 (SPF); Grão Mogol, 12/Oct./2001, Rivadavia 1262 (SPF); Itacambira, beirando a estrada M.Claros-Itacambira, 16/Dec./1994, Rivadavia 309 (SPF); Itacambira, estrada para M.Claros, 5/Mar./1997, Rivadavia 603 (SPF); Itacambira, estrada para M.Claros, 13/Oct./2001, Rivadavia 1291 (SPF); Joaquim Felício, Serra do Cabral, estrada entre J.Felício e Francisco Dumont, 3/July/2003, Rivadavia 1664 (SPF); Joaquim Felício, Serra do Cabral, a 22km de J.Felício, Rivadavia 1664, 3/Jul./2003 (SPF).

Drosera $\times$ fontinalis is morphologically most similar to $D$. tomentosa (see Figure 4 ), which differs in having leaves usually flat, oblong-obovate, petioles $0.4-3.0 \mathrm{~mm}(0.02-0.12 \mathrm{in})$ wide, lamina 1.3-6.0 mm (0.05-0.24 in) wide, and seeds more ovoid. The hybrid also resembles small specimens of $D$. ascendens A. St.-Hil., which differs in usually being much larger and more robust, but especially in its lacrimoid seed.

The distribution and length of eglandular hairs on leaves and inflorescences of the hybrid is variable from site to site, due to the fact that both $D$. grantsaui and $D$. tomentosa are themselves extremely variable in this character. The inflorescence of $D$. $\times$ fontinalis may reach $36 \mathrm{~cm}$ (14 in) in length (Rivadavia 603 at SPF), which is longer than in any of the numerous dried specimens examined for both parental species (maximum of $26.5 \mathrm{~cm}$ (10.4 in) in D. grantsaui and $33 \mathrm{~cm}$ (13 in) in D. tomentosa), showing a touch of hybrid vigor.

Drosera $\times$ fontinalis occurs in permanently wet to humid seepage habitats, sometimes on live Sphagnum spp., in boggy humus-rich soil, or in wet sand mixed with black peat. Similar to $D$. tomentosa, the hybrid is most often found in flower between the middle of the dry season and early in the wet season (approximately from June to November).

Large numbers of $D . \times$ fontinalis are often observed, at some places apparently more abundant than one or even both parental species. This suggests that either asexual reproduction may be common, possibly through the roots, or else $D . \times$ fontinalis may be fertile, although no seeds have germinated in cultivation. Drosera $\times$ fontinalis is especially abundant on highlands surrounding the three towns of Grão Mogol, Botumirim, and Itacambira (Minas Gerais) between c.700-1330 m (2300$4360 \mathrm{ft}$ ) altitude and on the northern part of the Chapada dos Veadeiros highlands (Goiás), at c.1400$1500 \mathrm{~m}(4600-4900 \mathrm{ft})$ altitude.

Although D. tomentosa is abundant throughout the Chapada Diamantina highlands (Bahia), $D$. grantsaui is only known from two small populations near the towns of Catolés and Piatã, respectively at $c .1550 \mathrm{~m}(5100 \mathrm{ft})$ and $c .1370 \mathrm{~m}(4500 \mathrm{ft})$ altitude, where both species are sympatric and a small number of $D . \times$ fontinalis have been observed. On the Serra do Cabral (Minas Gerais), once again $D$. grantsaui is only known from two small populations where it is sympatric with the more abundant $D$. tomentosa. Curiously, $D . \times$ fontinalis was only observed at the northernmost of the two locations, at $c .1200 \mathrm{~m}(3950 \mathrm{ft})$ altitude. 
Single small populations of $D$. grantsaui surrounded by larger populations of $D$. tomentosa, but without any signs of $D . \times$ fontinalis, were also observed near Serranópolis (Minas Gerais), on the Serra do Cipó (Minas Gerais), on the Serra da Canastra highlands (Minas Gerais), and on the southern side of the Chapada dos Veadeiros.

Inexplicably, no $D . \times$ fontinalis plants have ever been observed in a wide area surrounding the town of Diamantina (including Gouveia, São Gonçalo do Rio Preto, and Milho Verde in Minas Gerais), where $D$. grantsaui and $D$. tomentosa are abundant and frequently occur sympatrically. (see Figure 2)

The epithet "fontinalis" refers to the fact that $D . \times$ fontinalis was always found growing in natural springs, where water seeps continuously over wet soil.

Acknowledgements: I would like to thank Rolf Grantsau for the botanical drawings; Andreas

Figure 2: Map showing the known distribution of Drosera $x$ fontinalis Rivadavia (x-symbols) and locations where the parental species have been observed, but no hybrids (filled triangles). Sites indicated on the map may represent more than one collection listed in this paper.
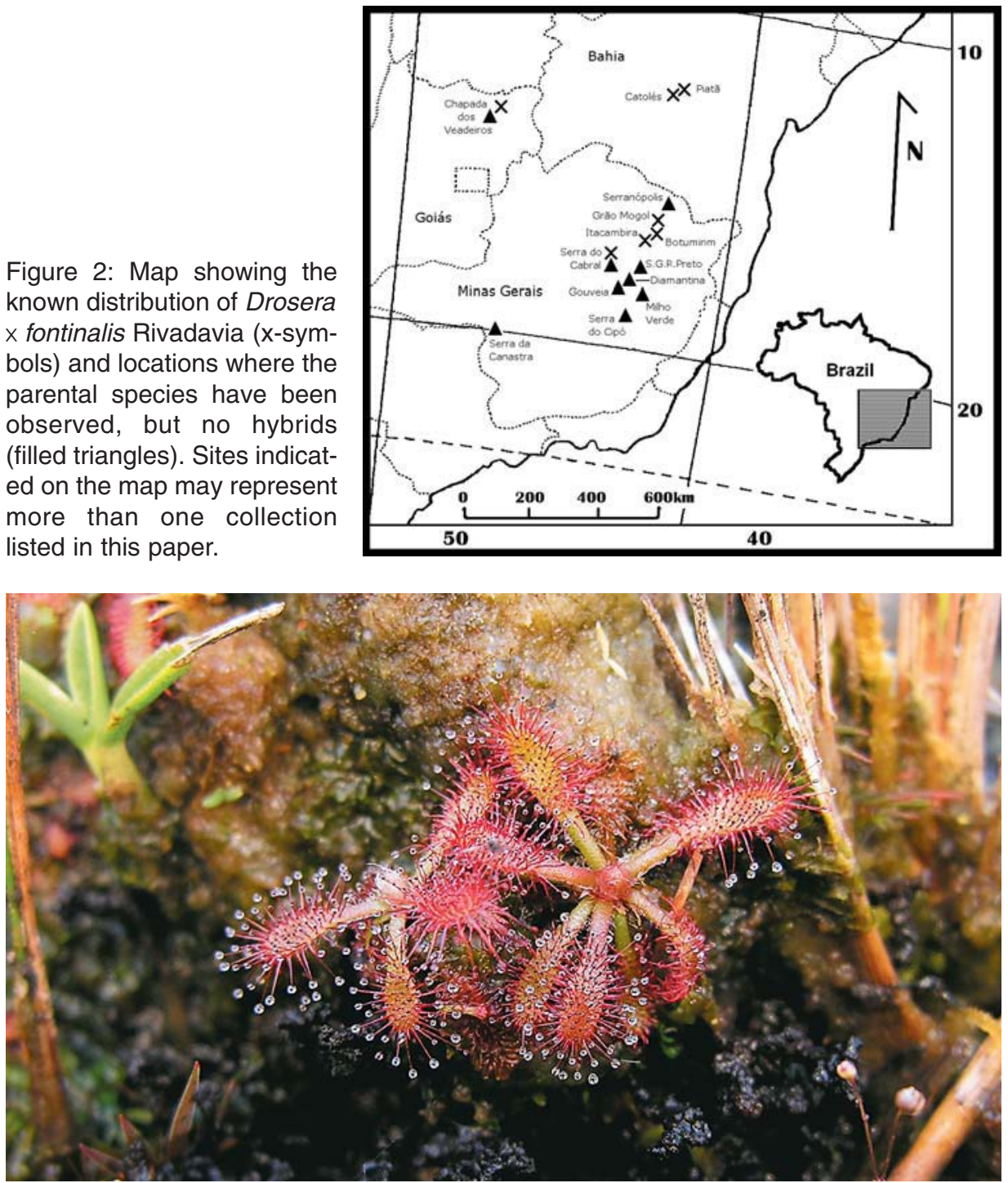

Figure 3: Drosera x fontinalis Rivadavia at the Chapada dos Veadeiros. 


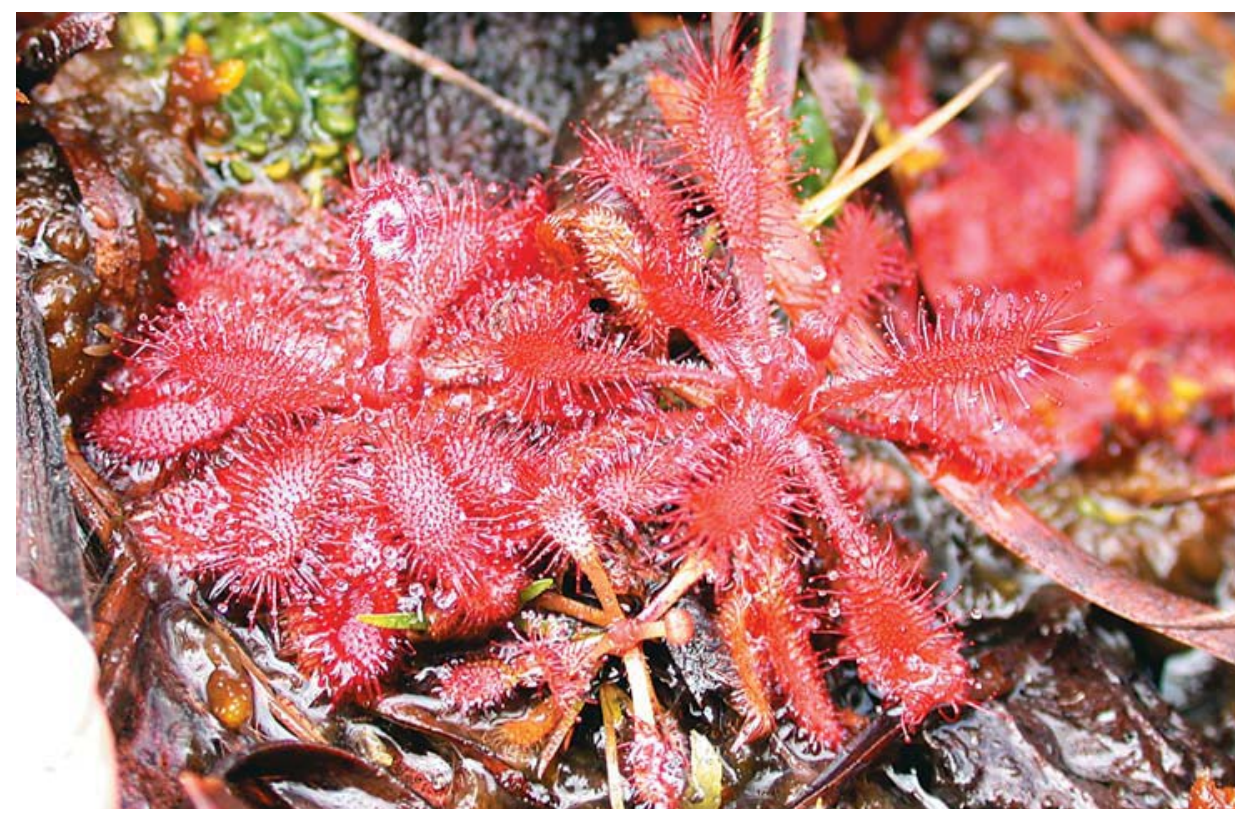

Figure 4: Drosera tomentosa A.St.-Hil. var. tomentosa (left) and $D . \times$ fontinalis Rivadavia (right) at Piatã, Chapada Diamantina. Genlisea aurea A.St.-Hil. can be seen in the background. Photograph by Ed Read.

Fleischmann for helpful comments and suggestions on this manuscript and for the Latin description; Paulo Gonella for help measuring, photographing, and organizing herbarium specimens; Ed Read for permission to use his photograph; as well as the many friends who joined me on numerous expeditions to study these plants in the field.

\section{References:}

Gibson, R., and Green, E. 1999. Drosera $\times$ corinthiaca (Droseraceae), a newly recognized natural hybrid from the Cape Province, South Africa. Carniv. Pl. Newslett. 28: 81-84.

Hoshi, Y., Hizume, M., and Kondo, K. 1994. Genomic in situ hybridization to improve a hypothesis on natural-hybrid origin of the hexaploid Drosera spatulata 'Kansai type'. La Kromosomo II-75-76: 2619-2623.

Kusakabe, I. 1979. Japanese Drosera hybrids. Carniv. Pl. Newslett. 8: 54.

Lowrie, A., and Conran, J. 2007. A revision of the Drosera omissa/D. nitidula complex (Droseraceae) from south-west Western Australia. Taxon 56: 533-544.

Nakano, M., Kinoshita, E., and Ueda, K. 2004. Life history traits and coexistence of an amphidiploid, Drosera tokaiensis, and its parental species, D. rotundifolia and D. spatulata (Droseraceae). Plant Species Biology 19: 59-72.

Rivadavia, F. 2003. Four new species of sundews, Drosera (Droseraceae), from Brazil. Carniv. Pl. Newslett. 32: 79-92.

Schnell, D. 2002. Carnivorous plants of the United States and Canada. Timber Press. Portland, USA. pp. 285-287.

Snyder, I. 2000. Colchicine treatment on sterile hybrid sundews. Carniv. Pl. Newslett. 29: 4-10. Wood, C.E. 1955. Evidence for the hybrid origin of Drosera anglica. Rhodora 57: 105-130.

Ziemer, B. 2002. Carnivorous Plant Photo Finder: http://cpphotofinder.com/Drosera.html, accessed 6/2008 